\title{
ULUM AL-QURAN, SEJARAH DAN PERKEMBANGANNYA
}

\author{
Wahyuddin dan M.Saifulloh*
}

\begin{abstract}
Abstrak
Al-Qur'an adalah wahyu llahy (kitab suci) yang diturunkan kepada Nabi Muhammad saw. sebagai pedoman hidup bagi umat manusia. Untuk memahami Al-Qur'an diperlukan berbagai ilmu, antara lain adalah "Ulum Al- Qur-an". IImu ini mencakup pembahasan-pembahasan yang berhubungan dengan Al-Qur'an dari segi sebab turunnya, pengumpulan dan urutan-ururannya, pengetahuan tentang ayat-ayat makkiyah dan madaniyyah, nasikh dan mansukh dan lain- lain. Ulum Al- Qur'an dengan berbagai cabang dan macamnya tidak lahir sekaligus, tetapi melalui proses dan perkembangan yang dapat dibagi ke dalam fase periwayatan dan fase kodifikasi. Sampai saat ini telah lahir puluhan tokoh di bidang Ulum AlQur'an, diantara mereka yang paling masyhur adalah Jalaluddin Al Suyuthi yang menulis kitab Al Itqan fi 'Ulumil Qur-an dan Al Zarqany dengan karyanya Al Burhan fi 'Ulumil Qur-an. Kedua kitab ini selalu menjadi rujukan dalam kajiankajian Ulumul Qur-an.
\end{abstract}

Kata kunci : Ulum Al-Qur'an, sejarah, perkembangannya

Al-Qur'an merupakan sumber utama ajaran Islam, dan juga merupakan pedoman hidup bagi setiap manusia. Al-Qur'an bukan sekedar memuat petunjuk tentang hubungan manusia dengan Tuhannya, tetapi juga mengatur hubungan manusia dengan sesamanya, bahkan hubungan manusia dengan alam sekitarnya (Choiruddin Hadliri:1993) Dengan deimkian, untuk dapat memahami ajaran Islam secara sempurna, maka langkah pertama yang harus dilakukan adalah memahami Al-Qur'an.

Al-Qur'an, sebagaimana diketahui, diturunkan dalam bahasa Arab, baik lafal maupun uslubnya. Namun demikian, tidaklah berarti bahwa semua orang Arab, atau orang yang mahir dalam bahasa Arab, dapat memahami Al-Qur'an secara rinci. Bahkan menurut Ahmad Amin (1975) para Sahabat sendiri tidak sanggup memahami kandungan Al-Qur'an dengan hanya sekedar mendengarkannya dari Rasulullah saw, karena menurut beliau, memahami Al-Qur'an tidak cukup dengan menguasai bahasa Arab saja.

*Unit Penyelenggara Mata Kuliah Sosial Humaniora (UPM SosHum)

jsh Jurnal Sosial Humaniora, Vol 6 No.1, Juni 2013 
T.M. Hasbi Ash-Shiddieqy (1980) menyatakan bahwa : untuk dapat memahami Al-Qur'an dengan sempurna, bahkan untuk menterjemahkannya, diperlukan sejumlah ilmu pengetahuan yang disebut dengan ilmu-ilmu Al-Quran, atau didalam istilah bahasa Arab dikenal dengan istilah ulum al-Qur'an. Permasalahannya adalah : apakah yang dimaksud dengan ulum al-Qur'an itu ? bagaimana sejarah dan perkembangannya? Siapa saja tokoh-tokoh ulum al-Qur`an dan kitab-kitab apa saja telah mereka lahirkan dalam bidang ini ?

Tulisan ini mencoba membahas ketiga permasalahan tersebut di atas. Dengan kata lain, tulisan ini memiliki tiga tujuan utama, yaitu : pertama, untuk menjelaskan pengertian ulum al-Qur`an, kedua mengungkapkan sejarah dan perkembangan ulum Qur`an, ketiga, memperkenalkan sejumlah kitab-kitab ulum al- Qur`an, beserta pengarangnya masing-masing.

\section{Pengertian Ulum al-Qur'an}

Istilah ulum al-Qur'an, secara etimologi, merupakan gabungan dari dua kata bahasa Arab: Ulum dan al-Qur'an . kata ulum adalah bentuk jamak dari kata ilm yang merupakan bentuk masdar dari kata alima, ya 'lamu yang berarti : mengetahui (Mahmud Yunus: 1990). Dalam kamus al-Muhit kata alima disinonimkan dengan kata arafa (mengetahui, mengenal). Dengan demikian, kata ilm semakna dengan ma'rifah yang berarti "pengetahuan". Sedangkan ulum berarti: sejumlah pengetahuan.

Adapun kata Qur'an, dari segi isytiqaqnya, terdapat beberapa perbedaan pandangan dari para ulama. Anatara lain, sebagaimana yang diungkapkan oleh muhammad bin Muhammad Abu Syaibah (1992) dalam kitab Al-Madkhal li Dirasah al-Qur'an al-Karim, sebagai berikut:

1. Qur'an adalah bentuk masdar dari qara'a, dengan demikian, kata Qur'an berarti "bacaan". Kemudian kata ini selanjutnya, sebagaimana bagi kitab suci yang diturunkan oleh Allh swt. Kepada nabi Muhammad saw, pendapat ini didasarkan pada firman Allah: Artinya "apabila kami telah seesai membacanya 
maka ikutilah bacaannya. (QS. Al Qiyamah : 18). Antara lain yang berpendapat demikian adalah al-Lihyan (w.215 H).

2. Qur'an adalah kata sifat dari al-qar'u yang bermakna al-jam'u (kumpulan). Selanjutnya digunakan sebagai nama bagi kitab suci yang diturunkan kepada nabi Muhammad saw, alas an yang dikemukakan adalah karena AlQur'anterdiri dari sekumpulans suruh dan ayat, memuat kisah-kisah, perintah dan larangan, dan juga karena Al-Qur'anmengumpulkan inti sari dari kitabkitab yang diturunkan sebelumnya. Pendapat ini, antara lain dikemukakan oleh al-Zujaj (w.311 H).

3. Kata al-Qur'an adalah ism alam, bahkan kata bentukkan dan sejak awal digunakan sebagai nama bagi kitab suci yang diturunkan oleh Allah SWT kepada nabi Muhammad saw, pendapat ini diriwayatkan dari Imam Syafi'y (w.204 H).

Menurut Abu Syahbah, dari ketiga pendapat di atas, yang paling tepat adalah pendapat yang pertama. yakni bahwa Al-Qur'an dari segi isytiqaqnya, adalah bentuk masdar dari kata qara'a.

Sedangkan Al-Qur'an menurut istilah, antara lain, adalah: Firman Allah swt yang diturunkan kepada Nabi Muhammad saw, yang memiliki kemukjizatan lafal, membacanya bernilai ibadah, diriwayatkan secara mutawatir, yang tertulis dalam mushhaf, dimulai dengan surah al-Fatihah dan diakhiri dengan surah al-Nas. (Muhammad Abu Syahbah: 1992).

M. Qurais Shihab (1997) mendefinisikan Al-Qur'an sebagai : “firman-firman Allah yang disampaikan oleh malaikat jibril sesuai redaksinya kepada Nabi Muhammad saw, dan diterima oleh ummat Islam secara tawatur.

Maka dapat didefinisikan bahwa: Al-Qur'an adalah firman Allah swt yang diturunkan kepada Nabi Muhammad saw melalui perantara malaikat Jibril a.s sesuai dengan redaksinya, yang memiliki kemukjizatan lafal, yang tertulis dalam mushaf, dimulai dari suruh al-Fatihah sampai pada suruh al-Nas, dan disampaikan secara mutawatir kepada umat Islam, dimana membacanya dinilai sebagai ibadah.

Berdasarkan beberapa pengertian ulum dan Al-Qur'an yang telah dikemukakan di atas, maka ulum yang didasarkan kepada Al-Qur'an memberikan 
pengertian bahwa ilmu ini merupakan kumpulan sejumlah ilmu yang berhubungan dengan Al-Qur'an (Ramli Abdul Wahid : 1994).

Sementara itu, secara terminology ulum al-Quran didefinisikan oleh para pakar dibidang ini, dengan sangat beragam. Namun demikian, semua pengertian yang dimaksud tidak akan dikemukakan dalam tulisan ini. Berikut ini dikemukakan dua pengertian ulum al- Qur'an, masing-masing dikemukakan oleh Manna al_Qattan dan Muhammad Abd al-Azim al-Zarqaniy.

Ulum al- Qur'an , menurut Manna' al-Qattan (1973) adalah: “Ilmu yang mencakup pembahasan-pembahasan yang berhubungan dengan Al-Qur'an, dari segi sebab turunnya, pengumpulan dan urutan-urutannya, pengetahuan tentang ayat-ayat makkiyyah dan madaniyyah, nasikh dan mansukh, mahkam dan mutasyabih, dan hal-hal lain yang berkaitan dengan Al-Qur'an.

Selanjutnya, al-Zarqaniy (tanpa tahun) memberikan definisi yang tidak jauh berbeda dengan al-Qattan, bahwa ulum al-Qur'an adalah: "Beberapa pembahasan yang berhubungan dengan Al-Qur'an dari segi turunnya, susunannya, pengumpulannya, penulisannya, bacaannya, tafsirnya, kemukjizatan, naskh dan mansukhnya, penolakan dari hal-hal yang bisa menimbulkan keraguan terhadapnya, dan sebagainya"

Dua definisi tentang ulum al-Quran yang dikemukakan di atas, pada dasarnya tidak memiliki perbedaan yang berarti. Keduanya justru sepakat dalam dua hal penting, yaitu : Pertama, bahwa ulum al-Qur'an adalah sejumlah ilmu pengetahuan yang membahas tentang Al-Qur'an. Kedua, masing-masing membuka peluang kemungkinan masuknya aspek lain ke dalam pembahasan ulum al-Qur'an, dalam pengertian bahwa, keduanya tidak memberikan batasan yang pasti tentang jumlah ilmu-ilmu yang masuk dalam kategori ulum al- Quran.

Sedangkan perbedaan yang Nampak pada keduanya hanya pada aspek pembahasan yang ditampilkan, yang menurut penulis, semata-mata hanya sebagai contoh untuk memudahkan pemahaman terhadap definisi yang dimaksud.

Dengan demikian, yang dimaksud ulum al-Qur'an adalah sejumlah ilmu pengetahuan yang secara khusus membahas tentang Al-Qur'an dari berbagai aspeknya. Sehingga sangat sulit untuk menentukan berapa banyak cabang dari ilmu 
ini. Abu Bakar bin al-Arabiy (w.544 H0. Misalnya, menyebutkan bahwa ulum alQur'an terdiri atas 77.450 ilmu, sesuai dengan banyaknya kata-kata dalam AlQur'an dikalikan empat. Sebab setiap kata dalam Al-Qur'an memiliki makna zahir batin, terbatas dan tak terbatas. 'Sedangkan al-Sayutiy (w.911 H) dalam kitabnya alItqan fiy "Ulum al-Qur'an" menyebutkan 80 macam ilmu Al Qur'an, bahkan menurut beliau jumlah tersebut masih dapat dibagi hingga mencapai 300 macam atau lebih.

Namun demikian, diantara sekian banyak cabang dari ulum al-Qur'an tersebut, menurut T.M. Hasbi Ash-Shiddieqy (1990), ada 17 cabang di antaranya yang paling utama, yaitu :

1. Ilm Mawatin al-Nuzul, yaitu ilmu yang menerangkan tempat-tempat turunnya ayat.

2. Ilm Tawarikh al-Nuzul, yaitu ilmu yang menerangkan dan menjelaskan masa turunnya ayat dan tertib turunnya.

3. Ilm Asbab al-Nuzul, yaitu ilnu yang menerangkan sebab-sebab yang melatar belakangi turunya ayat.

4. Ilm Qira'ah, yaitu yang menerangkan tentang macam-macam bacaan Al-Qur'an, mana yang sahih dan mana yang tidak sahih.

5. Ilm al-Tajwid, yaitu ilmu tentang cara membaca Al-Qur'an, tempat memulai dan pemberhentiannya, dan lain-lain.

6. Ilm Garib al-Qur'an, yaitu ilmu yang membahas tentang makna kata-kata (lafal) yang ganjil, yang tidak lazim digunakan dalam bahasa sehari-hari.

7. Ilm I'rab al-Qur'ani, yaitu ilmu yang membahas tentang kedudukan suatu lafal dalam kalimat (ayat), begitu pula tentang harakatnya.

8. Ilm Wujud wa al-Nazarir, yaitu ilmu yang menjelaskan tentang lafal-lafal dala Al-Qur'an yang meiliki banyak arti, dan menerangkan makna yang dimaksud pada suatu tempat.

9. Ilm Ma'rifah al-Muhkam wa al-Mutasyabih, yaitu ilmu yang membahas tentang ayat-ayat yang dipandang muhkam dan ayat-ayat yang dianggap mutasyibah. 
10. Ilm Nasikh wa al-Mansukh, yaitu imu yang menerangkan tentang ayat-ayat yang dianggap mansukh oleh sebagian ulama.

11. Ilm Bada'ii al-Qur'an, yaitu ilmu yang membahas tentang keindahan susunan ayat-ayat Al-Qur'an, menerangkan aspek-aspek kesusasteraan Al-Qur'an, serta ketinggi balagahnya.

12. Ilm I'jaz al-Qur'an, yaitu ilmu yang secara khusu membahas tentang segi-segi kemukjizatan Al-Qur'an.

13. Ilm Tanasub Ayat al-Quran, yaitu ilmu yang membahas tentang kesesuaian suatu ayat dengan ayat sebelum dan sesudahnya.

14. Ilm Aqsam al-Qur'an, yaitu ilmu yang membahas tentang arti dan tujuan sumpah Tuhan dalam Al-Qur'an.

15. Ilm Amsal al-Qur'an, yaitu ilmu yang membahas tentang perumpamaanperumpamaan yang terdapat dalam Al-Qur'an.

16. Ilm Jidal al-Qur'an, yaitu ilmu yang membahas tentang bentuk-bentuk debatan yang dikemukakan dalam Al-Qur'an, yang ditujukan kepada segenap kaum musyrikin, dan lain-lain.

17. Ilm Adab Tilawah al-Qur'an, yaitu ilmu yang membahas segala aturan yang harus dipakai dan dilaksanakan dalam membaca Al-Qur'an.

Demikianlah beberapa cabang dari ulum al-Qur'an yang paling utama. Ilmuilmu Al-Qur'an tersebut teramat penting dalam memahami dan menafsirkan AlQur'an, sehingga sebagian ulama menyebutkan ulum al-Qur'an dengan istilah usul al-tafsir, dan T.M Hasbi Ash Shiddieqy menyebutkan pula dengan nama ilmu-ilmu tafsir.

\section{Sejarah dan Perkembangan Ulumul Qur'an}

Sebagai ilmu pengetahuan yang berdiri sendiri, ulum al-Qur'an tidak lahir sekaligus, melainkan melalui proses pertumbuhan dan perkembangan. Istilah ulum al-Qur'an itu sendiri tidak dikenal pada masa awal pertumbuhan Isam. Istilah ini baru muncul pada abad ke 3, tapi sebagaian ulama berpandangan bahwa istilah ini 
lahir sebagai ilmu yang berdiri sendiri pada abad ke 5. Karena ulumul Qur'an dalam arti, sejumlah ilmu yang membahas tentang Al-Qur'an, baru muncul dalam karya Ali bin Ibrahim al-Hufiy (w.340), yang berjudul al-Burhan fiy Ulum al-Quran (Al Zarqaniy :35).

Untuk mendapatkan gambaran tentang perkembangan ulum al-Qur'an, berikut ini akan diuraikan secara ringkas sejarah perkembangannya.

Pada masa Rasulullah saw, hingga masa kekhalifahan Abu Bakar (12 H-13 H) dan Umar (12 H-23H) ilmu Al-Qur'an masih diriwayatkan secara lisan. ${ }^{\dagger}$ Ketika zaman kekhalifaan Usman (23H-35H) dimana orang Arab mulai bergaul dengan orang-orang non Arab, pada saat itu Usman memerintahkan supaya kaum muslimin berpegangan pada mushaf induk, dan membakar mushaf lainnya yang mengirimkan mushaf kepada beberapa daerah sebagai pegangan. Dengan demikian, usaha yang dilakukan oleh Usman dalam mereproduksikan naskah Al-Qur'an berarti beliau telah meletakkan dasar ilm rasm al-Qur'an (Subhiy Salih: 1977).

Selanjutnya, pada masa kekhalifaan Ali bin Abi Thalib, $(35 \mathrm{H}-40 \mathrm{H})$ beliau telah memerintahkan Abu al-Aswad al-Duwali (w.69 H) untuk meletakkan kaedahkaedah bahasa Arab. Usaha yang dilakukan oleh Ali tersebut, dipandang sebagai peletakan dasar ilmu I'rab al-Qur'an.

Adapun tokoh-tokoh yang berjasa dalam menyebarkan ulum al- Qur'an melalui periwayatan, adalah :

1. Khulafa al-Rasyidin, Ibnu Abbas, Ibnu Mas'ud, Zaid bin Tsabit, Ubai bin Ka'ab, Abu Musa al-Asya'ariy, dan Abdullah bin Zubair. Mereka itu dari golongan sahabat.

2. Mujahid, Ata, Tkrimah, Qatadah, Hasan Basri, Said bin Jubair, dan Zaid bin Aslam. Mereka golongan tabi'in di Madinah.

3. Malik bin Anas, dari golongan tabi'I tabi'in, beliau memperoleh ilmunya dari Zaid bin Aslam.

Mereka inilah yang dianggap orang-orang yang meletakkan apa yang sekarng ini dikenal dengan ilmu tafsir, ilmu asbab al-Nuzul, ilmu nasikh dan mansukh, ilmu garib al-Qur'an, dan lain-lain. (Al Zarqaniy : 30 - 31) 
Pada abad kedua hijriah, upaya pembukaan ulum al-Qur'an mulai dilakukan, namun pada masa ini perhatian ulama lebih banyak terfokus pada tafsir. Diantara ulama tafsir pada masa ini adalah : Sufyan Sau'ry (w.161 H), Sufyan bin Uyainah (w.198 H). wakil-wakil al-Jarah (w.197 H), Sybah bin al-Hajjaj (w.160 H). Muqatil bin Sulaiman (w.150 H). Tafsir-tafsir mereka umumnya memuat pendapat-pendapat sahabat dan tabi'in. (Abu Syahbah: 1992)

Pada masa selanjutnya, abad ke $3 \mathrm{H}$, muncullah Muhammad ibn Jarir alTabariy (w.310 H) yang menyusun kitab tafsir yang bermutu karena banyak memuat hadis-hadis sahih, ditulis dengan rumusan yang baik. Di samping itu, juga memuat I'rab dan kajian pendapat. ${ }^{\star}$ Pada masa ini juga telah disusun beberapa $u l u>m$ al Qur'ani yang masing-masing berdiri sendiri, antara lain: Ali ibn al-Madiniy (w.234 H) menyusun kitab tentang asbab al-nuzul, Abu Ubaid al-Qasim ibn Sallam (w.224 H) menyusun kitab tentang naskh dan mansukh. Ibnu Qutaibah (w.276 H) menyusun kitab tentang musykil al-Qur'an, Muhammad bin Ayyub al-Darls (294 H) menyusun tentang ayat yang turun di Mekah dan Madinah. Dan Muhammad ibn Khalf ibn al-Mirzaban (w.309) menyusun kitab al-Hawiy fiy Ulu>m alQur'an.(Subhiy Salih: 1977)

Pada abad ke $4 \mathrm{H}$, lahir beberapa kitab ulu>m al-Qur'an, seperti: Aja'ib ulu>m al-Qur'an karya Abu Bakar Muhammad ibn al-Qasim al-Anbary (w.328 H), dalam kitab ini dibahas tentang kelebihan dan kemuliaan Al-Qur'an, turunnya AlQur'andalam tujuh huruf, penulisan mushaf, jumlah surah, ayat dan kata dalam AlQur'an. Di samping itu, Abu al-Hasan al-Asy'ary (w.324 H) menyusun kitab alMukhtazan fiy Ulum al-Quran, Abu Bakar al-Sajastaniy (w.330 H) menyusun kitab tentang Garib al-Qur'an, Abu Muhammad al-Qasab Muhammad ibn Ali al-Karkhiy (w.sekitar 360 H) menyusun kitab Nakt al-Qur'an al-Dallah al-Bayan fiy Anwa alUlum wa al-Ahkam al-Munabbiah'an Ikhtilaf al-Anam. Pada masa ini juga Muhammad ibn Ali al-Adfawiy (w.388 H) menyusun al-Istigna' fiy Ulum alQur'an.

Demikianlah perkembangan $u l u>m$ al- Qur'an pada abad pertama hingga abad kjeempat, dapat dilihat bahwa para tokoh hanya membahas cabang-cabang 
иlити al - Qur'an, secara terpisah-pisah. Selanjutnya, pada pada abad ke 5 muncullah Ali bin Ibrahim ibn Sa'id al Hufiy (w.430 H) yang menghimpun bagianbagian dari ulum al Qur'an dalam karyanya al-Burhan fiy Ulum al-Qur'an. Dalam kitabnya ini, beliau membahas Al-Qur'anmenurut suruh dalam mushaf, selanjutnya beliau menguraikannya berdasarkan tinjauan al-Nahwu dan al-Lugah, kemudian mensyarahnya dengan tafsir bi al-Masur dan tafsir bi al-Ma'qul, lalu dijelaskan pula tentang waqaf (aspek qira'at), bahkan tentang hokum yang terkandung dalam ayat. Atas dasar inilah maka uluma menganggap al-Hofiy sebagai tokoh pertama yang membukukan ulumul Qur'an.(Manna al Qattan : 1973)

Selanjutnya, pada abad ke-6, Ibn al-Jauziy (w.597 H) menyusun kitab Funun al-Afinan fiy Ulum al-Qur'an, dan kitab al-Mujtaba fiy Ulum Tata'allaq bi alQur'an. Selanjutnya disusul oleh Alamuddin al-Sakhawiy (w.641 H) pada abad ke 7 $\mathrm{H}$ dengan kitabnya yang berjudul Jamal al-Qurra wa Kamal al-Iqara, kemudian Abu Syamah (w.665 H) menyusun kitab al-Mursyid al-Wajid fiy Ma Yata'allahq bi al-Qur'an al-Aziz. Pada abad ke 8 al-Zarkasyi (w.794 H) menyusun kitab al-Burhan fiy Ulum al-Qur'an. Lalu pada abad 9, Jalal al-Din al-Bulqniy (w.824 H) menyusun kitab Mawaqi' al-Ulum fiy Mawaqi al-Nujum. Pada masa ini pula Jalal al-Din alSayoty (w.911 H) menyusun kitab al-Tahbir fiy Ulum al-Tafsir dan kitab al-itqan fiy Ulum al-Qur'an.

Setelah wafatnya al-Sayuti pada tahun $911 \mathrm{H}$, seolah-olah perkembangan $u l u>m$ al-Qur'an telah mencapai puncaknya, sehingga tidak terlihat penulis-penulis yang memiliki kemampuan seperti beliau. Hal ini menurut Ramli Abdul Wahid (1994) disebabkan karena meluasnya sikap taklid di kalangan umat Islam, yang dalam sejarah ilmu-ilmu agama umumnya mulai berlangsung setelah masa al-Sayuti (awal abad ke -10 H) sampai akhir abad ke-13 H.

Selanjutnya, sejak penghujung abad ke-13 H hingga saat ini, perhatian ulama terhadap $u l u>m$ al-Qur'an bangkit kembali. Pada masa ini pembahasan dan pengkajian Al-Qur'antidak hanya terbatas pada cabang-cabang 'ulu>m al-Qur'an yang ada sebelumnya, melainkan telah berkembang, misalnya penterjemah AlQur'an kedalam bahasa asing. Juga telah disusun berbagai kitab 'ulu>m al-Qur'an, diantaranya ada mencakup bagian-bagian (cabang-cabang) 'ulu>m al-Qur'an secara 
keseluruhannya, ada pula yang hanya sebagian. Diantaranya ulama yang menysuusn kitab Ulumul Qur'an yang mencakup sebagian besar cabang-cabangnya adalah Tahir al-Jazayiri dalam bukunya : al-Tibyan li Ba'd al-Mabahis al-Muta'alliqah bi al-Qur'an pada tahun 1335 H. begitu pula Syekh Mahmud Abu Daqiqah, seorang ulama besar al-Azhar, menyusun kitab tentang ulum al-Qur'an. Setelah itu, Muhammad Ali selama menyusun kitab Manhaj al-Furqan fiy Ulum al-Qur'an yang mencakup berbagai cabang ilmu-ilmu Al-Qur'an. Kemudian disusul oleh Muhammamd Abd al-Azim al-Zarqaniy dengan bukunya Manihil irfan Fiy Ulum alQur'an. Selanjutnya, Ahmad Aliy menyusun kitab Muzakkirah Ulum al-Qur'an dan Subhi Salih menyusun kitab Mabahis fiy Ulum Qur'an.(Manna al Qattan :hal. 15)

Kitab-kitab lain yang juga lahir pada masa ini adalah Mahabis fiy Ulum alQur'an, karya Manna' al-Qattan, al-Tibyan fiy Ulum al-Qur'an, karya Ali alSaboni, Ulum al-Qur'an wa al-Hadis, karya Ahmad Muhammad Ali Daud. Dalam bahasa Indonesia dikenal pula T.M. hasbi sh-Shiddieqy dengan karyanya: Ilmu-Ilmu Al-Qur'an.

\section{Tokoh-tokoh Ulumul Qur'an dan karyanya}

Pada bagian terdahulu telah dikemukakan sejumlah tokoh ulum al-Qur'an berikut karya ilmiahnya. Di antara mereka terutama yang hidup sebelum anad ke-5 $\mathrm{H}$, hanya membahas bagian-bagian tertentu dari 'ulum al-Qur'an. Maka pada bagian ini akan dikemukakan sejumlah tokoh yang membahas ulum al-Qur'an dengan merangkum cabang-cabang 'ulum al-Qur'an dalam karya-karya mereka. Dan kitabkitab mereka inilah yang sebenarnya disebut kitab 'ulum al-Qur'an . tokoh-tokoh yang dimaksud:

1. Ali ibn Ibrahim ibn Sa'id al-Hofiy $(w .430 \mathrm{H})$ karyanya : al-Burhan fiy 'Ulum al-Qur'an.

2. Ibn al-Jauziy (w.597 H), karyanya: Funun al-Afinan fiy Aja'ib 'Ulum dan alMujtaba' fiy 'Ulum Tata'allaq bi al-Qur'an.

3. Abu Syamah (w.665 H), karyanya: al-Mursyid al-Wajiz Fi Ma Yata'allaq bi alQur'an al-Aziz. 
4. Badr al-Din al-Zarkasyi (w.794 H) karyanya : al-Burhan fiy 'Ulum al-Qur'an.

5. Jalal al-Din al-Sayuti (w.911 H). karyanya: al-Tahbir fiy 'Ulum al-Tafsir dan al-Itqan fiy 'Ulum al-Qur'an.

6. Tahir al-Juzairi, al-Tibyan fiy 'Ulum al-Qur'an.

7. Muhammad Ali Salamah, Manhaj al-Furqan fiy 'Ulum al-Qur'an

8. Muhammadi Abd al-Azim al-Zarqaniy, karyanya :Manahil irfan fiy 'Ulum alQur'an.

9. Ahmad Ali, Karyanya: Muzakkarah 'Ulum al-Qur'an.

10. Subhi Salim, Mabahis fiy 'Ulum al-Qur'an.

11. Manna al-Qattan, karyanya : Mabahis fiy 'Ulum al-Qur'an.

12. Ahmad Muhammad Ali Daud, karyanya: 'Ulum al-Qur'an wa al-Hadis.

13. Abu Bakar Ismail, Dirasat fiy 'Ulum al-Qur'an.

14. Muhammad Ali al-Sabuniy, al-Tirbyan fiy 'Ulum al-Qur'an.

Masih banyak tokoh dan kitab yang membahas tentang 'ulum al-Qur'an. Namun tokoh-tokoh yang telah disebutkan inilah yang lebih dikenal, dan buku-buku mereka menjadi rujukan bagi penulis dan peneliti tentang 'ulum al-Qur'an saat ini. Di antara mereka yang paling terkenal adalah al-Sayuti dengan kitabnya Íal-Itqan”. Kitab ini terdiri atas dua juz, dan membahas 80 jenis 'ulum al-Qur'an . begitu pula al-Zarkasyi yang lebih dahulu dari al-Sayuti, dalam kitabnya al-Burhan fiy Ulum alQur'an yang terdiri dari 4 jilid beliau membahas 47 jenis 'ulum al-Qur'an.

\section{Kesimpulan}

'Ulum al-Qur'an adalah beberapa pembahasan yang terkait dengan AlQur'an dari segi : tempat, waktu dan sebab turunya wahyu, lafal dan uslub bahasanya, kesusasteraan (Balaghah)-nya, penulisannya, pengumpulannya, bacaannya, naskh-mansukhnya, tafsirnya dan hal-hal lain yang terkait dengan AlQur'an.

'Ulum al-Qur'an yang terdiri dari berbagai macam dan cabangnya tidak lahir sekaligus, melainkan mellui proses perkembangan yang dapat dibagi ke dalam fasefase : (1) fase periwayatan, mulai zaman Rasulullah saw hingga awal abad ke-2 (2) fase lahirnya cabang-cabang 'ulum al-Qur'an dan kodifikasinya, mulai abad ke-2 
hingga abad ke-5 dan (3) fase kondifikasi 'ulum al-Qur'an sebagai suatu ilmu yang mencakup berbagai ilmu Al-Qur'an, yaitu sejak abad ke-5 hingga saat ini.

Hingga sat ini telah lahir puluhan tokoh di bidang 'ulum al-Qur'an, diantara mereka yang paling termasyhur adalah Jalil al-Din al-Sayuti pengarang kitab alItqan fiy 'ulum al-Qur'an dan al-Zarqasyi pengarang kitab al-Burhan fiy ulum alQur'an. Kedua kitab ini masih ada hingga sekarang dan menjadi rujukan bagi kajian-kajian 'ulum al-Qur'an. 


\section{Daftar Pustaka}

Abdul Wahid, Ramli, 1974 'Ulum al-Qur'an, Cet II; Jakarta: PT. Raja Grafindo Persada.

Abu Syahbah, Muhammad ibn Muhammad, 1992/1412 H. al-Madkhal li Dirasah alQur'an al-Karim, Beirut: Dar al-Jil.

Amin, Ahmad, 1975, Fajar al-Islam, Cet.XI; Beirut: Dara al-Kutub.

Arkoun, Muhammad, 1997, Lectures Du Coran, diterjemahkan oleh Machasin, Berbagai Pembacaan Al-Qur'an, (Seri INIS: no. 29;Jakarta:INIS).

Departemen Agama, 1989, Al-Qur'an dan Terjemahnya, Bandung: Gema Risalah Press.

Ibnu Khaldon, Muqaddinmah Ibnu Khaldun, Jilid I, t.tp: Dar al-Bayan t.th.

Al-Qattan, Manna'1973, Mabahis fiy Ulum al-Qur'an, Beirut: al-Muttahidah li alTawzi.

Al-Saboniy, Muhammad Ali, 1987, al-Tibyan Fiy Ulum al-Qur'an, diterjemahkan oleh Moch. Chudlori Umar dan Moh. Matsna, Pengantar Studi Al-Qur'an, Bandung: al-Ma'arif.

Saleh, Subhi, Mahabis Fiy Ulum al-Qur'an, Cet. IX; Beirut: Dar al-Ilm li alMalayin.

Al-Sayutiy, Jalal al-Din, al-Itqan fiy Ulum al-Qur'an, Juz I, Beirut: Dar al-fikr, t.th.

Ash-Shiddieqy, 1980, Sejarah dan Pengantar Ilmu Al-Qur'anTafsir, Cet. VIII: Jakarta : Bulan Bintang,

Shibab, Quraish, 1996, Wawasan Al-Qur'an: tafsir Maudhu'I atas berbagai Persoalan Umat, Bandung: Mizan.

Yunus, Mahmud, 1990, Kamus Arab-Indonesia, Jakarta: Hidakarya Agung, Yunus, Kamus Arab-Indonesia

Al-Zarqaniy, Muhammad Abd al-Azim, t.th, Manahil Irfan fiy Ulum al-Qur'an, Juz I, Mesir Isra al-Babiy al-Halaby. 